УДК 377.016:[75:004.9](07)

DOI: 10.37026/2520-6427-2021-106-2-153-159

\section{Олена ВЛАСЮК,}

кандидат педагогічних наук, доиент кафедри образотворчого

та декоративно-прикладного мистецттва

Інституту мистеитв

Рівненського державного

гуманітарного університету,

м. Рівне, Україна

ORCID: 0000-0003-4454-8433

e-mail:olena.vlasyuk1@gmail.com

\title{
СПЕЦИФІКА ВИКОРИСТАННЯ КОМП'ЮТЕРНИХ ТЕХНОЛОГІЙ У ПРОФЕСІЙНІЙ ПІДГОТОВЦІ ФАХІВЦІВ МИСТЕЦЬКОГО НАПРЯМУ
}

\begin{abstract}
Анотація. У статті проаналізовано сучасні тендениії соиіально-економічного розвитку, процес розиирення культурних та освітніх зв'язків України з іншими краӥнами, що викликають значний попит на високопрофесійних фахівиів у різних галузях діяльності. Окреслено мету професійної підготовки, щчо передбачає набуття високого рівня професійних знань, навичок та мобільності відповідно до вимог науково-технічного прогресу та ринкових відносин в економічі, виховання сочіально активних членів суспільства, формування наукового сприйняття, творчого мислення, національної свідомості.

Схарактеризовано досвід використання комп'ютерних технологій у ході професійної підготовки фахівиів мистецького напряму. Дослідження трунтується на застосуванні педагогічного, теоретичного та практичного досвіду, щзо дало змогу проаналізувати основні шляхи підвищення ефективності підготовки майбутніх фахівців мистецького напряму засобами інформаційного супроводу навчального процесу.
\end{abstract}

Обгрунтовано зростання обсягу інформачії в умовах інформатизації суспільства, щуо спричинило необхідність інтенсивного впровадження комп 'ютерних технологій у навчальний процес закладів вищої освіти. Доведено актуальність означеного завдання у підготовці фахівиів різного профілю.

У публікаиії окреслено досвід використання комп'ютерних технологій у ході професійної підготовки майбутніх фахівців мистецького напряму у контексті сприймання, структурування, систематизації, збереження великих обсягів навчального матеріалу. Доведено, щзо комп 'ютерні технології дозволяють істотно підвищити ефективність навчання. Презентовані результати емпірично-експериментальної роботи, здійсненої автором статті.

Ключові слова: комn 'ютерні технології, електронні засоби інформаційного супроводу навчання, електронне методичне забезпечення, електронні підручники, електронні навчальні програми, електронні тренажери.

Olena VLASIUK,

PhD, Associate Professor of Art and

Decorative and Applied

Art department of Institute of Arts,

Rivne State University of the Humanities,

Rivne, Ukraine

ORCID: 0000-0003-4454-8433

e-mail: olena.vasyuk1@gmail.com

\section{SPECIFICS OF COMPUTER TECHNOLOGIES USE IN THE PROFESSIONAL TRAINING OF ART SPECIALISTS}

\begin{abstract}
The article deals with the expediency of the introduction of certain forms and methods at the lessons, presents the results of empirical and experimental work, carried out by the author of the article in three higher educational establishments of Ukraine.

The modern tendencies of social and economic revival and rebirth of the Ukrainian society spirit, expanding of cultural relations of Ukraine with other countries cause a great demand in highly professional specialists in all fields of the professional activity, which also leads to the growing
\end{abstract}

importance of their effective professional training. At present the aim of the professional training is acquiring high level professional knowledge, habits, skills and mobility, which meet the demands of scientific and technological progress and market relations in economics, upbringing of the socially active members of the society, formation of scientific perception, creative thinking, best human qualities and national consciousness.

The purpose of this article is to analyze the experience of using computer technology in the training of future artists. 
The research is based on the application of theoretical and practical pedagogical experience, which made it possible to analyze the main ways of improving the efficiency of professional training of future designers by means of information support of the educational process. The constant increase in the amount of information in the conditions of informatization of society has led to the necessity of intensive introduction of computer technologies into the educational process of higher education institutions. This task is relevant for the training of professionals of different profiles. The article analyzes the experience of using computer technology in the training of future designer's context of perception, structuring, systematization, preservation of large volumes of educational material in order to improve the level of success and quality of training. Computer technologies make it possible to significantly improve the training.

Key words: computer technologies, electronic facilities of information provision of studies, electronic methodological provision, electronic textbooks, electronic curriculum program, electronic trainers.

Постановка проблеми. Постійне зростання обсягу інформації в умовах інформатизації суспільства спричинило необхідність інтенсивного впровадження комп'ютерних технологій у навчальний процес закладів вищої освіти. Означене завдання $є$ актуальним для підготовки фахівців різного профілю, зокрема майбутніх фахівців мистецького напряму. Шляхами його реалізації є застосування електронних засобів інформаційного супроводу: електронних підручників, навчальних посібників, електронного методичного забезпечення навчальних дисциплін, електронних засобів контролю знань студентів та оцінки якості засвоєння навчального матеріалу, електронних баз даних, призначених для інформаційної підтримки дисциплін тощо.

Однак, як засвідчує практика, електронні засоби інформаційного супроводу ще недостатньо використовуються у ході навчання майбутніх фахівців мистецького напряму. У зв'язку з цим актуалізується проблема вдосконалення методичних параметрів навчального процесу через поширення та урізноманітнення означених засобів.

Аналіз наукових досліджень і публікацій. Теоретичну основу розв'язання виокремленої проблеми становлять праці вітчизняних та зарубіжних учених, присвячені питанням відповідності освіти вимогам суспільства (Андрущенко, 2005; Гріббл, 1998), модернізації освіти (Степко, Болюбаш, Лемківський, Сухарніков, 2004), інформатизації та комп'ютеризації освіти (Гуревич, 2008). Проблема інноваційних процесів у навчанні грунтовно досліджувалася науковцями різних галузей науки (Пометун, Пироженко, 2004; Шевчук, Фенрих, 2005). Проте питання, пов'язані із впливом інноваційних підходів на професійну підготовку студентів, досі залишаються нерозв'язаними. Зазначений аспект конкретизується дослідниками в контексті використання комп'ютерних технологій у закладах вищої освіти (Барановський, Образцов, Різун та ін., 1996).

Теоретичні роботи зарубіжних учених та практична діяльність провідних європейських навчальних закладів свідчать, що процес навчання повинен відповідати потребам суспільства та бути спрямованим на освоєння студентами комп'ютерних технологій у різних галузях (Добес, 1997; Певснер, 1990).

Зважаючи на відносну новизну викладених цими авторами положень і пропозицій, доцільно докладніше схарактеризувати можливості та перспективи інформатизації мистецької освіти.

Мета статті - проаналізувати досвід використання електронних засобів інформаційного супроводу в ході професійної підготовки майбутніх фахівців мистецького напряму.

Виклад основного матеріалу дослідження. У навчальному процесі закладів вищої освіти широко використовуються засоби IКТ, серед яких особливе місце належить інструментам візуалізації, значущість яких зумовлена низкою чинників. Адже у зв'язку із глобалізацією та інформатизацією всіх сфер людської життєдіяльності важливого значення у взаємодії людини зі світом набуває візуальний образ. Означене твердження особливо актуальне щодо молоді та дітей, які на відміну від попередніх поколінь не знають іншого світу - світу без глобального інформаційного простору, без інтернету з його яскравими образами та зображеннями. Домінування візуальності в різних сферах людської діяльності зумовило виникнення концепції так званого «покоління Z» та притаманного йому «кліпового» мислення, «мислення картинками». Крім того, візуалізація як засіб спрощення та узагальнення складних понять та парадигм, характерних науковому знанню, давно застосовується у педагогіці. Надзвичайно важливим $є$ використання методів унаочнення при підготовці майбутніх фахівців галузі мистецтва - тих, хто обрав своїм покликанням сферу, де образ, зображення, яскраве відображення дійсності є головними.

За даними дослідників (Образцов, Різун, Холод, 1996) застосування цих засобів значно підвищує результативність навчання студентів, оскільки забезпечує:

- по-перше, одночасну активізацію декількох каналів сприйняття (передусім аудіального та візуального), що уможливлює інтеграцію отриманої інформації 3 допомогою різних органів чуття;

- по-друге, візуалізацію абстрактної інформації, що сприяє кращому її розумінню;

- по-третє, відтворення алгоритмів складних процесів, що дає змогу простежити послідовність їх перебігу, глибше осягнути сутність.

Як бачимо, з допомогою електронних засобів інформаційного супроводу можна прискорити та полегшити процес отримання та обробки необхідної для вивчення інформації, ефективно впливати на розвиток пізнавальних якостей студентів.

Варто погодитися з П. Образцовим, що досягнення таких результатів стає можливим у випадку відповідності використання означених засобів низці умов:

- психологічних, згідно з якими представлення навчального матеріалу повинно відповідати індивідуальним можливостям студентів, зокрема вербально-логічному та сенсорно-перцептивному рівням особистісного розвитку, а його виклад необхідно орієнтувати на тезаурус та лінгвістичну композицію певної вікової категорії, а також конкретний напрям професійної підготовки; 
- дидактичних, що мають забезпечити реалізацію можливостей комп'ютерної візуалізації навчальної інформації на основі дотримання повноти (цілісності) і неперервності дидактичного циклу навчання, системність і структурно-функціональну зв'язність презентації навчального матеріалу, досягнення інтерактивного характеру навчання;

- методичних, що базуються на врахуванні своєрідності конкретного навчального предмета, специфіки відповідної науки та iï понятійного апарату, особливостей методів дослідження, можливостей реалізації сучасних методів обробки інформації і конкретизуються у таких позиціях, як: представлення навчального матеріалу з опорою на взаємозв'язок і взаємодію понятійних, образних і дієвих компонентів мислення; відображення системи термінів навчальної дисципліни у вигляді ієрархічної структури; надання студенту можливостей виконання різноманітних контролюючих тренувальних дій (Образцов, Різун, Холод, 1996).

Завдяки своїм можливостям електронні засоби інформаційного супроводу можна використовувати під час проведення всіх видів навчальних занять. Спробуємо проаналізувати декілька основних аспектів їх застосування у професійній діяльності.

Зрозуміло, що у зв'язку з обмеженістю в часі лектор у ході проведення заняття характеризує, як правило, лише основні поняття і дає студентам окремі вказівки та пояснення щодо змісту нового матеріалу. Логічно, що його візуалізація може сприяти як розширенню можливостей викладача щодо збільшення обсягу інформації, так і підвищенню ефективності їі сприйняття з боку студентів.

У процесі візуалізації навчальної інформації в межах вивчення таких тем курсів, як «Історія мистецтв», «Історія української культури», «Культурологія», використовувалися різноманітні методики та інтернет-сервіси. Зокрема, для відображення та засвоєння епохи, явища або процесу у вигляді набору ключових слів, так званої «хмари слів», використовувалися сервіси вільного доступу: безкоштовні англомовні сервіси Word It Out, Word Cloud Generation, Word Art, російськомовний слово-генератор Wordcloud.pro. Наприклад, для визначення культурних та мистецьких особливостей епохи Ренесансу студентами було створено хмару слів «Європейське Відродження» (див. рис. 1).

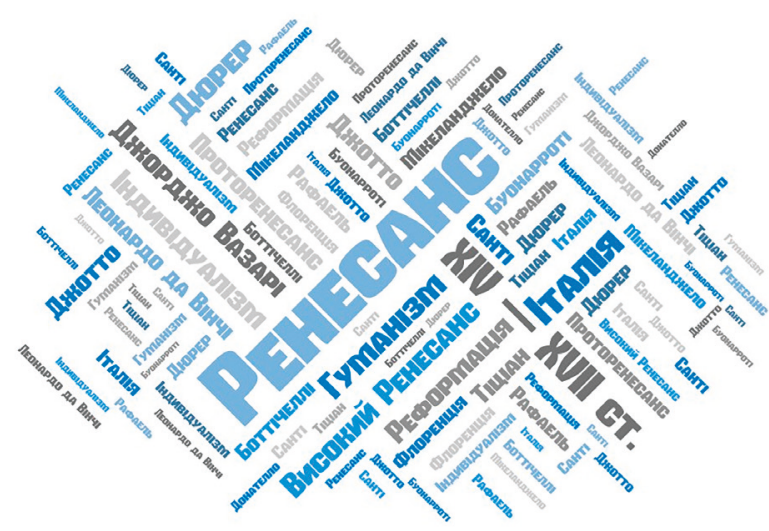

Рис.1. Хмара слів
Із метою формування уявлень про історію та тенденції розвитку різних галузей мистецтва та дизайну було організовано роботу з інтерактивними картами: Google Arts \& Culture, TimeMaps, Atlas of World History, GeaCron (див. рис. 2). Надзвичайно ефективним, зручним і корисним у використанні при вивченні історії мистецтва та дизайну виявився загальнодоступний ресурс Histography, де автоматично візуалізується послідовність певних історичних подій, роки життя видатних особистостей, здійснення наукових відкриттів, створення шедеврів мистецтва у межах обраного періоду тощо. Інтерактивні карти як візуалізоване відображення тих чи інших процесів сприяють не тільки вдосконаленню в студентів навичок використання IКТ у навчальній діяльності, а й розвитку логічного мислення, навичок аналізу та синтезу, співставлення явищ та процесів мистецької галузі з іншими сферами людської діяльності.

Навчальний процес засвідчив доцільність використання й такого інструменту візуалізації, як Timeline («Стрічка часу»), тобто створення за допомогою сервісів Timelime, ClassTools, Dipity подієво-часової стрічки, інтерактивної хронологічної шкали із фотографіями, текстами, ілюстраціями, покликаннями. Цікаві приклади створення таких стрічок часу пропонує сервіс Timetoast (https://www.timetoast.com/timelines/ arte-medievale-cfe5ea2c-8cd6-4e04-8342-55f6ecabd0da) (див. puс. 3).

Ефективним засобом унаочнення навчального матеріалу стали інтелект-карти (ментальні карти, карти пам'яті, mindmaps). Автор методики Т. Бьюзен створив сучасний та простий інструмент, незамінний для швидкого опрацювання великих об'ємів інформації та ефективного запам'ятовування. Використання загальнодоступних сервісів для візуалізації навчальної інформації забезпечує синтетичне представлення значних блоків інформації в компактній формі, що дозволяє не тільки унаочнювати відповідну інформацію, а й стимулювати активну пізнавальну діяльність майбутніх фахівців, розвивати аналітичні вміння та навички, здатність до моделювання як способу пізнання, асоціативне мислення (Андрущенко, 2005). Загальнодоступними та зручними додатками для розробки цих засобів є coggle. it, xmind.net, bubbl.us, wisemapping.com, mind42.com, mindomo.com, mindmeister та інші. Так, наприклад, за допомогою сервісу Coggle.it за результатами вивчення модулю «Стиль рококо» студентами було створено інтелект-карту (див. рис. 4).

Важливим є використання ІКТ під час вивчення студентами спецдисциплін «Основи поліграфії» та «Дизайн книги», оскільки навчальними планами передбачено засвоєння навичок роботи у спеціалізованих програмах InDesign, QuarkXPress, Pagemaker та пакетах для роботи з графічними файлами Corel, Photoshop, Illustrator тощо. Окремим напрямом використання ІКТ $є$ також навчання студентів основ педагогічної роботи за фахом за допомогою існуючих педагогічних програмних засобів, зокрема мультимедійних посібників О. М. Томецької. Однак специфіка матеріалу, методів та форм роботи цього напряму надзвичайно розлогі, а тому заслуговують висвітлення в окремій статті. 

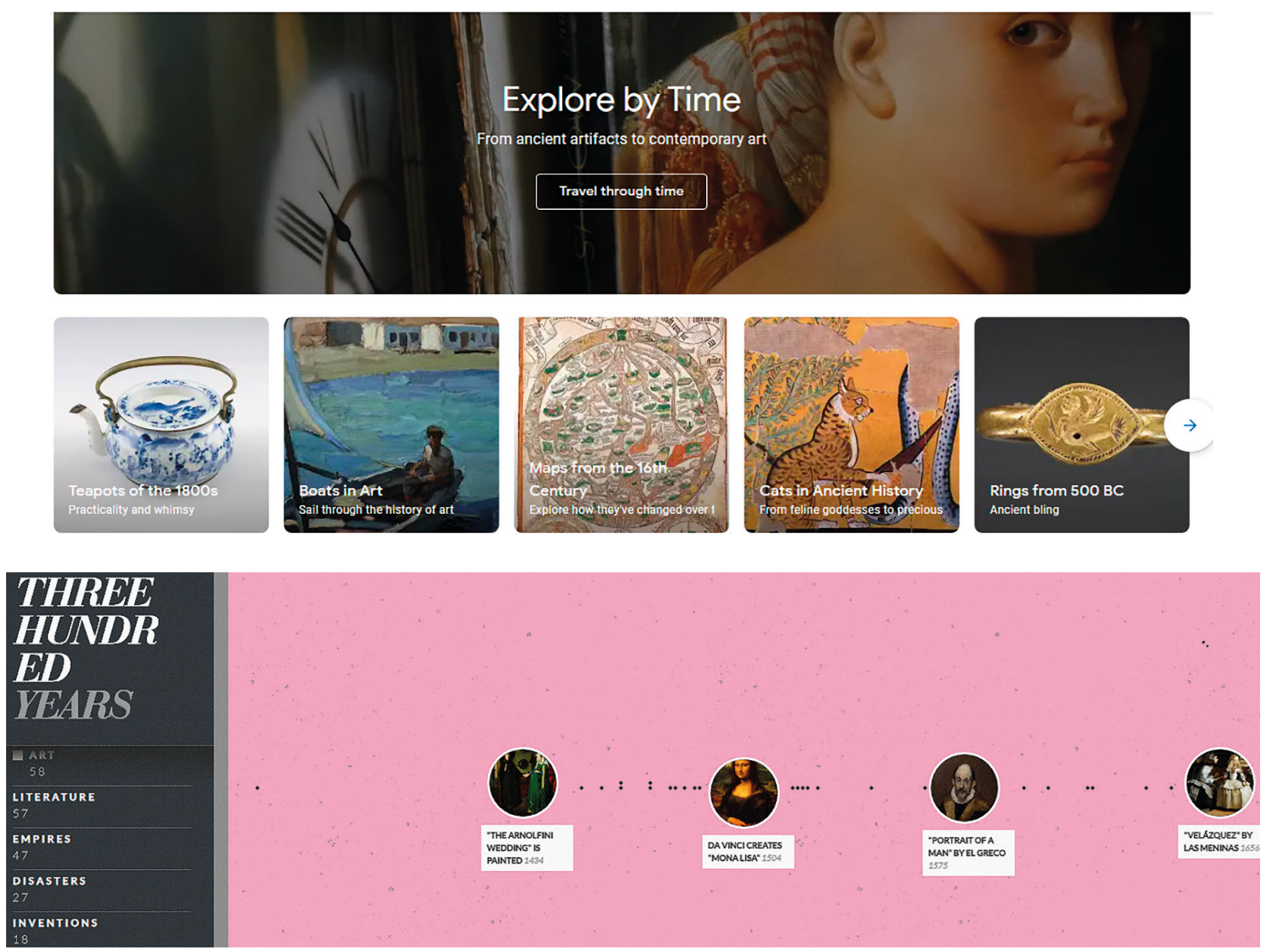

Puc. 2. Інтерактивна карта Google Arts \& Culture

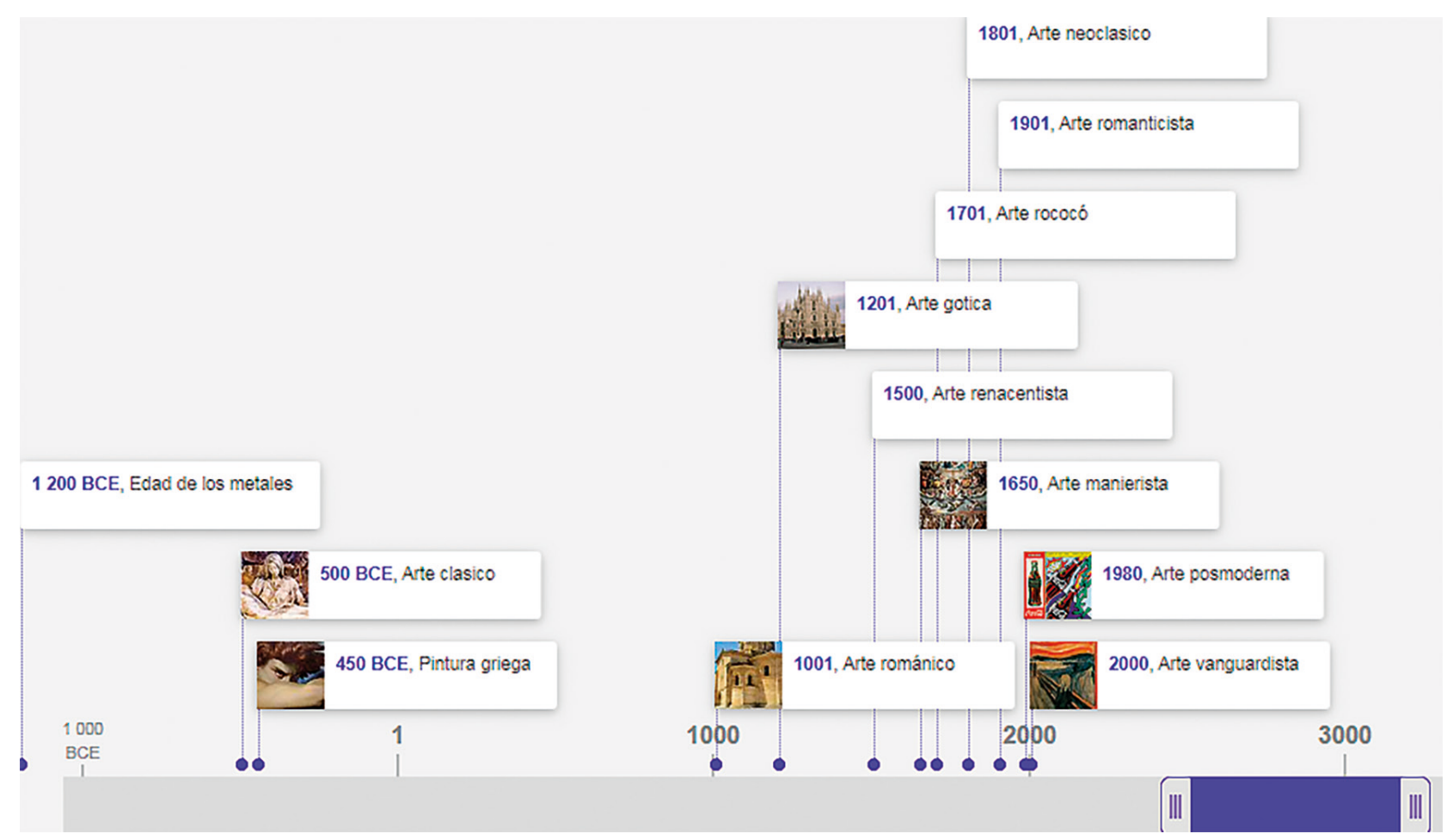

Pис. 3. Інтерактивна карта Timetoast 


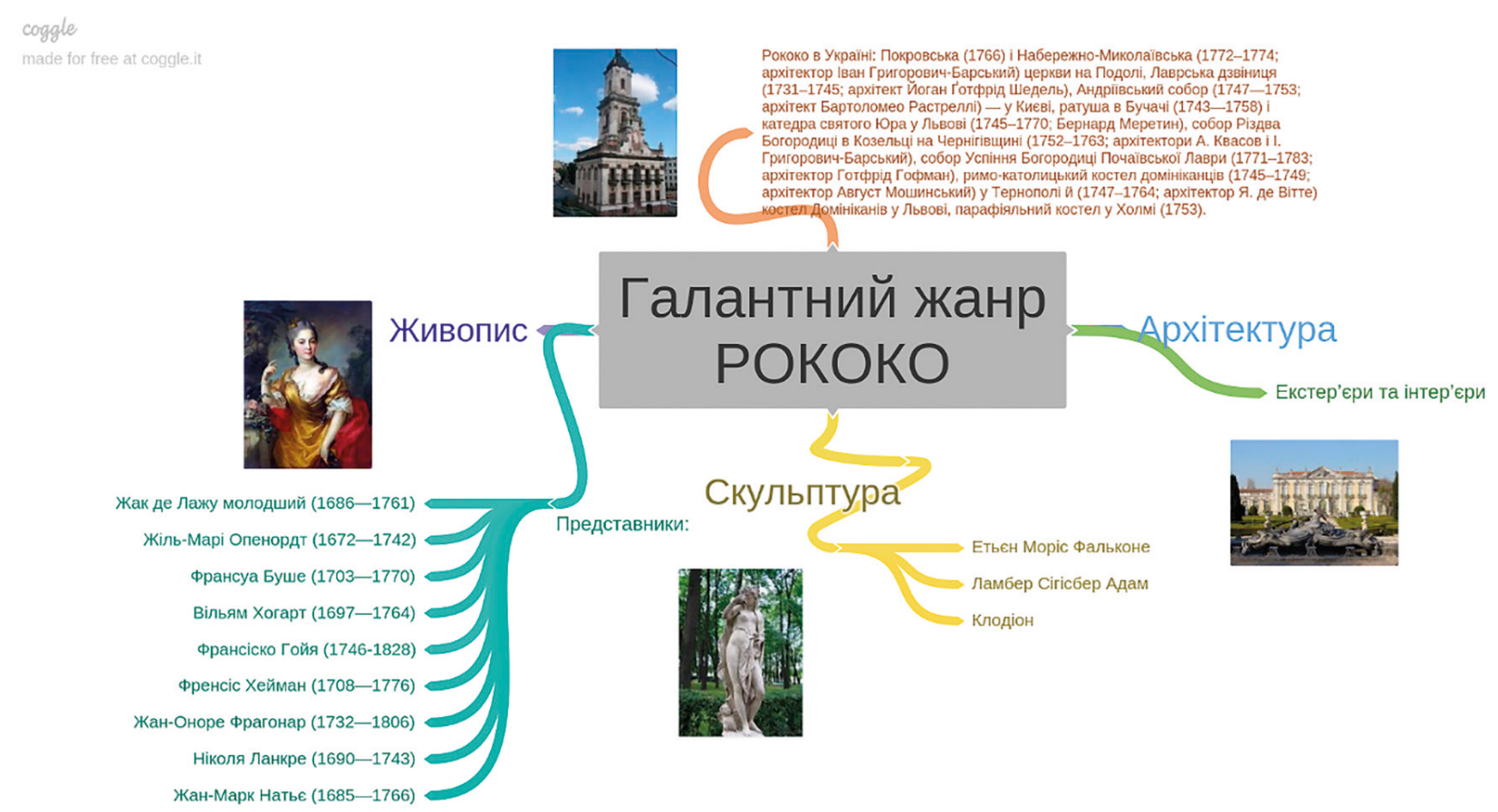

Рис. 4. Інтелект-карта «Стиль рококо»

Викладач, забезпечений комп'ютером, замість дошки та крейди отримує потужний інструмент для iii представлення в різноманітних формах: текстовій, графічній, анімаційній, цифрового відео тощо. Здобуваючи інформацію в електронному вигляді, студенти позбавлені необхідності ведення конспектів і можуть уважніше прислухатися до коментарів лектора.

Мультимедійні лекції можна використовувати в ході викладання всіх дисциплін, які входять до змісту професійної підготовки фахівців мистецького напряму: основ композиції, кольорознавства, історії мистецтв, історії дизайну тощо.

Отриманий нами досвід проведення таких лекцій засвідчує їх можливості щодо активізації пізнавальної діяльності студентів, підвищення швидкості та якості засвоєння навчального матеріалу. Крім того, під час лекцій із застосуванням електронних засобів інформаційного супроводу ми констатували посилення емоційних реакцій студентів. Як пояснює П. Образцов, це явище зумовлене можливостями означених засобів створювати особливе навчальне середовище, в якому значно збільшується обсяг навчальної інформації у вигляді відеофрагментів, фотографій тощо, що мають сильніший за традиційний емоційний вплив на людину і сприяють кращому розумінню й запам'ятовуванню побаченого (Образцов, Різун, Холод, 1996).

Під час мультимедійних лекцій варто звернути увагу на потенційні можливості використання різноманітних презентацій на великих екранах текстової, аудіальної, графічної, анімаційної та інших видів інформації, яка слугує ефективним засобом ілюстрації розповіді й пояснень викладача.

Безумовно, результативність презентації залежить передусім від проведеної попередньої підготовки, що вимагає:
- чіткого визначення цілі, завдання та типу заняття; - формування структури заняття;

- виокремлення етапів, на яких будуть застосовуватися електронні засоби інформаційного супроводу; - обрання найефективніших засобів (програм) та аналізу доцільності їх застосування;

- пошуку чи складання авторської програми у випадку нестачі електронного ілюстративного матеріалу;

- визначення тривалості використання обраних засобів (з урахуванням дидактичної мети і завдань, а також чинних санітарних норм) та здійснення хронометражу заняття;

- коригування структури заняття відповідно до норм часу, поставлених завдань та санітарних норм.

За умови оптимальної підготовки та використання у ході лекцій електронні засоби інформаційного супроводу дають змогу:

- підвищити інформативність лекції;

- урізноманітнити спектр наочних засобів навчання;

- забезпечити доступність інформації для сприйняття завдяки презентації інформації у візуальному та слуховому різновидах;

- здійснити повтор основних положень матеріалу попередньої лекції або необхідних (зокрема ключових, складних чи цікавих) моментів наявної лекції;

- підвищити інтерес та увагу студентів (зокрема у фазі ії закономірного зниження - через 25-30 хвилин після початку та в останні хвилини заняття) 3 допомогою естетично привабливих слайдів, анімації, звукового ефекту тощо;

- посилити мотивацію студентів до навчання;

- створити комфортні умови для роботи під час лекції викладачам та студентам.

Отримані сучасними дослідниками дані та наш практичних досвід підтверджують доцільність використання схарактеризованих засобів і в ході семінарських 
та практичних занять. Проте варто підкреслити той особливий ефект, що полягає у поступовому перетворенні електронного ресурсу з предмета навчальної діяльності студентів (щодо засвоєння знань про його специфіку, прийомів застосування) у засіб розв'язання різноманітних навчальних або професійних завдань. Адже під час роботи невеликої групи студентів можливо презентувати інформацію як на великому загальному екрані, так і на екранах моніторів персональних комп'ютерів. У такому випадку презентацію може проводити як викладач, так і студент, що дає змогу урізноманітнити зміст роботи з інформацією, сприяє формуванню вмінь і навичок роботи з електронними засобами інформаційного супроводу.

На сьогодні у зв'язку з дистанційним навчанням у закладах вищої освіти чимало уваги приділяється створенню й удосконаленню електронних підручників iз різних дисциплін, навчальних програм, електронних тренажерів, що стають незамінними засобами навчання на заняттях та у ході самостійної підготовки завдяки забезпеченню відповідного обсягу наочності. Їх використання значно розширює можливості майбутніх фахівців мистецького напряму щодо вивчення таких дисциплін, як «Історія мистецтв», «Основи композиції», «Історія української культури» тощо. Так, ознайомлення 3 програмою дає змогу краще спланувати свій час, визначити пріоритетні напрями самостійної роботи. Електронний підручник - це сконцентрований в одному джерелі великий обсяг ілюстрованої інформації.

Як бачимо, вдаючись до цих засобів, студент отримує швидкий доступ до потужного джерела інформації, що дає змогу не тільки покращити якість його теоретичної підготовки, а й вивільнити час для художньої діяльності, зекономити кошти, необхідні для придбання книг.

Електронні засоби інформаційного супроводу $\epsilon$ перспективними і щодо презентації різноманітних методичних рекомендацій та вказівок до вивчення навчальних дисциплін. Вони сприяють підвищенню ефективності підготовки студентів до семінарів чи практичних занять, організації самостійної роботи, написанню курсових, бакалаврських та дипломних робіт. Їх цінність полягає в тому, що кожен студент може виконувати навчальні завдання самостійно, послідовно і поетапно. Це значно розширює межі самостійності навчальної діяльності, підвищує якість дистанційного навчання та навчання за індивідуальним планом.

Одним із компонентів електронного супроводу навчальної дисципліни є демонстрація навчальних фільмів. Використовуючи відеоредактори, можна досить швидко змонтувати потрібний фільм із відзнятих фрагментів, накласти звук на відеоряд і додати необхідні коментарі (субтитри). Зрозуміло, що для створення навчального фільму потрібний дидактично доцільний якісний сценарій, який забезпечує логічний, послідовний та лаконічний (в умовах обмеження в часі) виклад навчального матеріалу.

Так, у ході підготовки фахівців мистецького напряму ефективними є фільми, що використовуються для вивчення дисциплін «Професійна та практична підготовка», «Дизайн в декоративному мистецтві», «Проєктування». Вони сприяють ознайомленню студентів з усіма етапами створення дизайн-проєкту, докладним аналізом технік та технологій його виготовлення.

Завдяки своїм можливостям метод демонстрації навчальних фільмів може бути використаний на лекції, практичному занятті, а також під час самостійного вивчення дисципліни. 3 огляду на це зазначимо, що використання електронних засобів інформаційного супроводу значно підвищує ефективність самостійної роботи студентів, вага і частка якої нині суттєво збільшилася, адже пошукові системи уможливлюють швидкий пошук максимального обсягу необхідної інформації. Крім того, означені засоби в змозі вплинути на зміну форм студентської самостійної роботи, переорієнтувати іiі на застосування моделюючих навчальних програм, електронних енциклопедій, довідників, посібників.

Використання електронних засобів інформаційного супроводу є результативним і під час проведення різноманітних форм контролю (поточного, проміжного, підсумкового). Так, популярне сьогодні комп'ютерне тестування забезпечує можливості для досить швидкого здійснення одночасного контролю знань усієї групи студентів, знижуючи при цьому рівень їх емоційного напруження та підвищуючи в такий спосіб мотивацію навчальної діяльності.

Сьогодні тестові завдання є надзвичайно поширеними і популярними, оскільки дозволяють швидко визначити рівень знань студентів, прискорити обробку отриманої інформації, охопити великі за обсягом масиви вивченого матеріалу. Зокрема, для створення тестових завдань надзвичайно зручно використовувати безкоштовний онлайн-ресурс Google Forms, що $\epsilon$ частиною офісного інструментарію Google Drive. Ресурс потребує встановлення плагіну Flubaroo і наявності акаунту Google. Це дозволяє створювати завдання різних форматів (наприклад, з одним або кількома варіантами відповіді або з вибором відповіді зі списку), додавати зображення та відео, зберігати документи, в яких фіксуватимуться результати оцінювання

Висновки. Отже, комп'ютерні технології та електронні засоби інформаційного супроводу дають можливість істотно підвищити ефективність навчання майбутніх фахівців мистецького напряму, забезпечуючи їх різноманітним та якісним теоретичним, ілюстративним, довідниковим, рекомендаційним матеріалом, що можна використовувати як під час проведення різних форм занять, так і в ході самостійної роботи. Їх застосування уможливлює прискорення пошуку й отримання необхідної для навчання інформації, економію часу і коштів, полегшує сприйняття навчального матеріалу, сприяє його розумінню та формуванню необхідних для майбутньої професійної діяльності вмінь і навичок.

Перспективи подальших досліджень в означеному напрямі стосуватимуться проблем удосконалення комп'ютерних технологій навчання здобувачів вищої освіти, систематизації електронного методичного забезпечення навчальних дисциплін, що входять до змісту професійної підготовки фахівців мистецького напряму, використання електронних засобів інформаційного супроводу з метою творчої активізації студентів. 


\section{СПИСОК ВИКОРИСТАНОЇ ЛІТЕРАТУРИ}

Андрущенко, В. П. (2005). Роздуми про освіту: статті, нариси, інтерв'ю. Київ: Знання України. 804 с.

Gribble, D. (1998). Real Education. London: Libertarian Education. 259 p.

Модернізація вищої освіти України і Болонський процес. (2004) / відп. ред. М. Ф. Степко. Київ: НМЦВО. $155 \mathrm{c}$.

Барановский, Ю. С. (2001). Информационные инновационные технологии в профессиональном образовании. Краснодар: Изд-во КубГТУ. 369 с.

Гуревич, Р. С. (2008). Інформаційно-телекомунікаційні технології в освіті. Київ: Юрінком Інтер. C. 364-365.

Пометун, О. І., Пироженко, Л. В. (2004). Сучасний урок. Інтерактивні технології навчання: науково-методичний посібник. Київ: А.С.К. 192 с.

Шевчук, П., Фенрих, П. (2005). Інтерактивні методи навчання: навчальний посібник. Щецин: WSAP. $170 \mathrm{c}$.

Образцов, П., Ризун, Н., Холод, Е. (1996). Дидактические аспекты эффективного применения компьютерных средств обучения в вузе: сб. научн. трудов. Вып. 2. Орел: ГТУ. С.468-475.

Dobesz, J. (1997). Artistyczne srodowisko Wroclawia okolo roku 1900. Sztuka okolo 2000 w Europie Srodkowej. Krakow: Miedzynarodowe Centrum Cultury. S. 123-131.

Pevsner, N. (1990). Academies of Art Past and Present. London: Cambridge University Press. 323 p.

\section{REFERENCES}

Andrushchenko, V. P. (2005). Rozdumy pro osvitu: statti, narysy, interviu [Reflections on education: articles, essays, interviews]. Kyiv: Znannia Ukrainy. 804 s. [in Ukrainian].

Gribble, D. (1998). Real Education. London: Libertarian Education. 259 r. [in English].
Modernizatsiia vyshchoi osvity Ukrainy i Bolonskyi protses [Modernization of higher education of Ukraine and Bologna process]. (2004) / vidp. red. M. F. Stepko. Kyiv: NMTsVO. 155 s. [in Ukrainian].

Baranovskyi, Yu. S. (2001). Ynformatsyonnye ynnovatsyonnye tekhnolohyy v professyonalnom obrazovanyy [Information innovative technologies in professional education]. Krasnodar: Yzd-vo KubHTU. 369 s. [in Russian].

Hurevych, R. S. (2008). Informatsiino-telekomunikatsiini tekhnolohii v osviti [Informational and telecommunication technologies in education]. Kyiv: Yurinkom Inter. S. 364-365. [in Ukrainian].

Pometun, O. I., Pyrozhenko, L. V. (2004). Suchasnyi urok. Interaktyvni tekhnolohii navchannia [Modern lesson. Interactive learning technologies. Scientific and methodical guide]: naukovo-metodychnyi posibnyk. Kyiv: A.S.K. 192 s. [in Ukrainian].

Shevchuk, P., Fenrykh, P. (2005). Interaktyvni metody navchannia [Interactive teaching methods]: navchalnyi posibnyk. Shchetsyn: WSAP. 170 s. [in Ukrainian].

Obraztsov, P., Ryzun, N., Kholod, E. (1996). Dydaktycheskye aspekty effektyvnoho prymenenyia kompiuternykh sredstv obuchenyia v vuze [Didactic aspects of effective application of computer facilities for teaching in the institute]: sb. nauchn. trudov. Vyp. 2. Orel: HTU. S.468-475. [in Russian].

Dobesz, J. (1997). Artistyczne srodowisko Wroclawia okolo roku 1900. Sztuka okolo 2000 w Europie Srodkowej. Krakow: Miedzynarodowe Centrum Cultury. S. 123-131. [in Polish].

Pevsner, N. (1990). Academies of Art Past and Present. London: Cambridge University Press. 323 p. [in English].

Дата надходження до редакиії: 04.03.2021 p. 